УДК: 001.891:929 (045)

Леся Михайлівна Микуланинець,

кандидат мистецтвознавства, доцент,

Мукачівський державний університет,

Мукачево, Україна,

e-mail: 1.mikulaninets@gmail.com,

ORCID: 0000-0002-6346-6532

\title{
ДОСЛІДНИЦЬКА ДІЯЛЬНІСТЬ ВАЛЕРІЇ ШУЛЬГІНОЇ У ДИСКУРСІ НАУКОВОЇ БІОГРАФІЇ
}

\begin{abstract}
Анотація. Метою статті $\epsilon$ розкриття особливостей дослідницької діяльності Валерії Дмитрівни Шульгіної з позиції наукової біографії, висвітлення значення вченої у розвитку національної мистецтвознавчої думки. Методологія публікації грунтується на застосуванні біографічного, аналітичного, історичного, системного підходів. У роботі доводиться твердження, що в епоху постмодернізму митець - інтерпретатор соціокультурних процесів. Вивчення його життєпису в дискурсі заявленої квестії сприяє залученню в сучасну гуманітаристику значного об’єму невідомих документів, архівних матеріалів, мемуарних джерел. Вони допомагають усвідомити індивідуально-психологічні риси креативної персони, зрозуміти логіку іiі життєвої стратегії, опанувати різноманітні виміри професійної практики, здобути конкретний досвід для вирішення сучасних онтологічних проблем.

Нині в мистецтвознавстві важливими є розвідки, що студіюють спадок визначних національних постатей, які уособлюють поступ України в європейський цивілізаційний простір. У цьому аспекті знаковою є особистість В. Шульгіної авторки великої кількості фундаментальних праць. Вона започаткувала нові наукові напрямки, виховала плеяду талановитих учених. Вагомою $є$ іiі організаційна практика, що включає проведення всеукраїнських та міжнародних
\end{abstract}


конференцій, форумів, творчих зустрічей. Серйозний внесок Валерії Дмитрівни в підготовку дослідницьких кадрів через: керівництво діяльністю аспірантів та докторантів, опонування на захистах дисертацій, рецензування авторефератів, роботу в спеціалізованих учених радах тощо. Спираючись на ідеї В. Шульгіної, представники гуманітаристики активно розвивають інноваційні методи, пізнають незнані сторінки української та світової культури. Наукова біографія мисткині $€$ свідченням яскравої філософії буття креативної неординарної жінки, що зуміла реалізувати власний багатогранний потенціал.

Ключові слова: життєпис, біографічний підхід, наукова біографія, гуманітаристика, вчений, дослідницька діяльність, Валерія Шульгіна

Вступ. Українське музикознавство інтенсивно розвивається, освоює нові методи вивчення культурних артефактів. Центром уваги мистецтвознавців усе частіше стає виявлення домінуючих об'єктивних та суб'єктивних чинників, які впливають на зміну духовних орієнтирів суспільства епохи постмодернізму. Можемо констатувати, злам XX та XXI ст., 3 одного боку, ознаменувався антропологічною кризою, з іншого - посиленням пієтету до індивідуума й пошуками його «Я», намаганням збагнути місію у бутті людства. Ці процеси активізували появу великого об'єму біографічних робіт у різних галузях гуманітарного знання. Така ситуація підтверджує думку - історію творять конкретні персони, й досліджуючи їх літопис, ми усвідомлюємо не лише специфіку творчого методу, але й закономірності певного виду діяльності.

Саме тому все більшої актуальності набуває біографічний підхід, де хроніки митця є засобом інтерпретації цивілізаційних практик. Значний інтерес отримує життєпис представників еліти. Вони тлумачаться каталізаторами трансформацій у визначеній галузі наукового i творчого існування. У цьому вимірі особистість ученого набуває значно 
глибшої експлікації. Утверджується постулат, що його постать тісно пов'язана 3 власними розвідками й органічно вплетена в громадський контекст. Такий погляд розширює межі традиційного мистецтвознавства, залучаючи в його поле філософію, соціологію, психологію, літературознавство, журналістику тощо. Це сприяє осягненню особливостей функціонування новітньої історії, розумінню культурної атмосфери мислителя, виявленню значення митця в конструюванні світоглядної моделі певного етносу, нації тощо.

Постановка проблеми. На сучасному етапі еволюції гуманітаристики життєписні роботи виходять на інший якісний рівень. З'являється їх значна кількість: інтелектуальна, літературна, творча, художня, альтернативна та інші біографії. Хроніки, які раніше були покликані лише вказувати на певні віхи буття особистості, нині збагачується аналізом професійних фактів, оцінкою основних фахових здобутків, осягненням їх аксіологічного суспільного змісту. Все частіше у працях ми зустрічаємо поняття «наукова біографія». Воно пояснюється в декількох аспектах: літопис вченого; комплекс способів пізнання персони, незалежно від поля іiі діяльності; характеристика напрацювань провідних дослідників різних галузей знань; документальне вивчення існування певного діяча. Даний термін ще не $є$ широковживаним та усталеним, тому часто він вбачається синонімом до дефініції «інтелектуальна біографія». Проте, ми інтерпретуємо його: життєпис суб'єкта, поданий у хронологічній послідовності та єдності з історичними й соціокультурними подіями конкретної країни, епохи, грунтується на достовірних фактах, що неодноразово піддавалися критичному розгляду. Через них розкривається трансформація поглядів індивідуума. Таким чином, наукова біографія поєднує риси традиційного літопису, який накладається на громадське тло з заглибленням у психологічну галузь об'єкту студіювання, вивчення продуктів його творчості. 
Для поступу мистецтвознавства особливої актуальності набувають біографічні праці, присвячені знаковим вченим, засновникам нових напрямів досліджень, лідерам наукових шкіл, вихователям плеяди яскравих послідовників. Своєю практикою вони уособили українську культуру, сприяли поступу держави в європейський цивілізаційний простір. У цьому контексті яскравою $є$ постать доктора мистецтвознавства, професора, автора понад 200 праць, людини, яка майже 60 років віддала розбудові національної гуманітаристики, - Валерії Дмитрівни Шульгіної. Аналіз ії діяльності у дискурсі наукової біографії спрямовує представлену статтю в трьохаспектну площину: історична та індивідуально-духовна реконструкція буття, оцінка концептуальних складових напрацювань, усвідомлення значення спадку мисткині інтелектуальною елітою країни.

Аналіз останніх досліджень і публікацій. Життєписні роботи посіли унікальне місце в гуманітаристиці, підтвердженням чому є значна кількість статей, присвячених окремим знаковим постатям. Дослідниками вивчається феномен біографії (О. Довгополова, В. Климчук, I. Колесник, Я. Мойсієнко та ін.), літопис як соціокультурне явище (В. Боднарчук, І. Голубович, С. Іконникова та ін.), хроніки індивідуума у контексті інтерпретації матеріальних і духовних надбань (О. Кривцун, Л. Микуланинець, О. Попович та ін.), способи використання біографічного методу (Н. Дічек, В. Ковальчук, І. Колесник, Н. Шарошкіна та ін.) та підходу (Н. Белан, В. Менжулін, Л. Микуланинець, Т. Росул) та ін. Росте число фундаментальних праць, що 3'ясовують риси таланту провідних національних діячів (О. Гедзь, У. Граб, М. Жишкович, Б. Косопуд, Н. Іванова, А. Палійчук та ін.).

Особливий інтерес складає особистість В. Шульгіної. Її наукові здобутки та викладацька практика неодноразово ставали теоретико-методологічним підгрунтям мистецтвознавчих i педагогічних розвідок (О. Афоніна, О. Берегова, С. Волков, 
Н. Гуральник, Г. Карась, О. Немкович, С. Садовенко, О. Яковлев та ін.). Предметом студіювання були і віхи діяльності мисткині (I. Бобришева, Т. Лестер, О.Овчарук, В. Чернець та ін.). Проте, поки що відсутні публікацій, які б виявляли специфіку творчих надбань Валерії Дмитрівни у вимірі наукової біографії.

Мета статті - на основі вивчення та узагальнення джерел у галузі гуманітаристики розкрити особливості дослідницької діяльності $\quad$ В. Шульгіної 3 позиції наукової біографії, висвітлити значення вченої у розвитку національної мистецтвознавчої думки.

Виклад основного матеріалу. Валерія Дмитрівна Шульгіна народилася 4 березня 1939 р. у Києві в надзвичайно інтелігентній сім'ї. Батько - Дмитро Павлович Скрипніченко багатогранна, освічена людина: музикував на флейті й фортепіано, професор, багаторічний завідувач кафедри науковотехнічної інформації Київського інституту культури. Мати Марія Стефанівна Шульгіна - закінчила інститут міжнародних відносин, а також була економістом. Художньо-творча атмосфера в родині, дружба зі знаними українськими діячами I пол. XX ст. - О. Палладіним (президент Академії наук), Я. Лепченко, В. Резніченко, О. Соколовським, П. Тутковським, (академіки Академії наук), В. Беліцером, Д. Фердманом (мікробіологи, члени-кореспонденти Академії наук) та ін. сформували світогляд Валерії Дмитрівни, ціннісне ставлення до мистецтва й науки, високі моральні якості, прагнення до самовдосконалення, потребу служити духовним цілям. Ці риси визначальні для дослідниці, вона пронесла їх крізь усе своє життя [1, с. 31$]$.

3 раннього дитинства В. Шульгіна професійно навчалася грі на фортепіано. Вона закінчила Київську спеціалізовану музичну школу ім. М. Лисенка та консерваторію. Студіювання за фахом проходило в одного з основоположників національної піаністики, прекрасного виконавця та викладача Є. Слівака. Під його наставництвом мисткиня опанувала значний 
різножанровий та різностильовий репертуар, досягла технічної досконалості, оволоділа широкою темброво-звуковою палітрою, набула сценічної свободи.

Після здобуття вищої освіти Валерія Дмитрівна працює у Чернігівському музичному училищі (1961р.), продовжує займатися концертною діяльністю. Товариські взаємини пов'язували іiі 3 видатними постатями української культури: Л. Грабовським, Р. Кофманом, Б. Лятошинським, А. Штогаренко й ін. Спілкування з ними поглибило захоплення вітчизняним мистецтвом, утвердило намір його популяризувати через власну педагогічну практику.

Бажання осягнути нові творчі вершини сприяли вступу мисткині до аспірантури Московського науково-дослідного інституту художнього виховання (1971р.). У зазначений період вона тісно контактує 3 академіками Є. Квятковським та В. Шацькою (під керівництвом останньої була захищена кандидатська дисертація), з прекрасним піаністом, професором Московської консерваторії Станіславом Нейгаузом. Дружні стосунки поєднували Валерію Дмитрівну з родинами Нейгаузів, Пастернаків, Прокоф'євих та ін. [1, с. 32]. Цілком закономірно, що така інтелектуально-творча комунікація мала великий вплив на подальший їі духовний розвиток. Паралельно з написанням дисертації аспірантка концертує та викладає у Київській консерваторії.

Оскільки постать В. Шульгіної $\epsilon$ багатогранною та масштабною, в рамках однісї публікації неможливо висвітлити всі аспекти іï діяльності. Тому сконцентруємо увагу на розкритті специфіки наукової роботи вченої.

Ще у студентські роки Валерія Дмитрівна зацікавилася питаннями теорії та методики музичної освіти, вивчала особливості національної культури. Тому обгрунтованим став вибір теми кандидатської дисертації, яка була присвячена проблемам української піаністики. 
31983 по 1989 pp. В. Шульгіна працювала в Київському педагогічному інституті (нині - Національний педагогічний університет ім. М. Драгоманова), а з 1989 по 1993 рр. завідувала кафедрою музики в Іссик-Кульському державному університеті в Киргизстані. Практика у ВНЗ визначила вектор дослідницьких пошуків Валерії Дмитрівни. Ї̈̈ статті, навчальні посібники та підручники, видані в даний період, присвячені різним професійним граням підготовки вчителя. Особливо цінними $є$ укладені нею репертуарні збірки та науково-методичні розробки. Вони покликані допомогти викладачам-початківцям при підборі дидактичного матеріалу, сприяють подоланню технічних та інтерпретаційних складностей, що виникають при формуванні учнів ДМШ.

За своїм змістом зазначені публікації реалізували авторську концепцію В. Шульгіної щодо креативного виховання на українській основі; вони здобули позитивні відгуки та офіційні рецензії провідних педагогів та науковців (Н. Вітте, Б. Кременштейн, І. Рябов, М. Угляр та ін.) і до сих пір не втрачають своєї значущості.

У 1993 р. В Шульгіна отримала вчене звання професора. 3 цього часу і до 2003 р. вона очолювала сектор нотних видань бібліотеки імені В. Вернадського, спрямовувала його дослідницьку діяльність. Під іiі орудою було систематизовано та введено в мистецтвознавчу думку унікальні музичні фонди, що містили вагому інформацію про вітчизняні культурні артефакти. Вони стали джерелознавчою основою докторської дисертації Валерії Дмитрівни («Музична україніка: інформаційний i національно-освітній простір», 2002 р.). Дана праця стала інноваційною та започаткувала новий напрям гуманітаристики.

32000 по 2010 pp. В. Шульгіна також викладала у Національній музичній академії ім. П. Чайковського. Окрім читання курсів лекцій, вона керувала студентськими дипломними роботами. Визначальним у іiі співпраці 3 майбутніми педагогами були активізація наукового потенціалу, 
творчий підхід, заохочення до виступів на конференціях, залучення до публікації статей у фахових журналах. Багато випускників мисткині НМАУ продовжили навчання в аспірантурі (Т. Зінська, Л. Микуланинець, М. Москалик, Л. Пискач, Д. Садовникова, О. Стебельська, Д. Титенко та ін.).

Авторка даної статті мала щастя студіювати у В. Шульгіної. Мене захоплювало майже все в постаті професорки: делікатна й витончена манера спілкування, вишуканий стиль одягу, вміння нести високі ідеали жіночності; талант побачити креативну ідею вихованця ще до того, як вона викристалізується у сформоване поняття, мудрість та далекоглядність у виборі теми магістерської праці та ін. У будьякій ситуації я була переконана, що викладачка зрозуміє та підтримає. Мабуть, саме ці особистісні якості згуртовували навколо Валерії Дмитрівни непересічних людей, сприяли іiі успішній діяльності на керівних посадах.

32003 р. і до сьогоднішнього дня В. Шульгіна працює у Національній академії керівних кадрів культури і мистецтв. Вона завідувала кафедрою музикології, а 32010 р. була головою Вченої ради $з$ захисту дисертацій Д 26.850.01. (спеціальність 26.00.01 - «Теорія та історія культури»). У НАКККіМ мисткиня розгорнула масштабну роботу. Зібравши команду інтелектуалівентузіастів, Валерія Дмитрівна стала авторкою великої кількості наукових проектів, ініціювала відкриття сучасних спеціалізацій («музикознавець-експерт», «продюсер», «імпресаріо» та ін.), налагодила міжнародні зв'язки. Очільниця спецради проводить значу дослідницьку та організаційну працю зі здобувачами.

В. Шульгіна $\epsilon$ членом редакційної колегії провідних фахових видань із мистецтвознавства, здійснює рецензування монографій, методичних збірок, авторефератів кандидатських та докторських дисертацій, систематично виступає офіційним опонентом.

Загалом можемо сказати, що роки незалежності відкрили нову сторінку в діяльності В. Шульгіної. Після тривалої ізоляції, 
починаючи 3 90-х pp. XX ст., Україна починає активно інтегровуватись у європейський соціокультурний простір. Валерія Дмитрівна одна 3 перших започатковувала та реалізовувала міжнародні наукові проекти. Їх місія - обмін досвідом із зарубіжними вченими, залучення вітчизняних науковців до роботи всесвітніх форумів та організацій, отримання різного роду грандів, стипендій. Дослідниця неодноразово виступала 3 повідомленнями в Греції, Іспанії, Італії, Німеччині, Норвегії, Польщі, Швейцарії, Шотландії та інших країнах. Її доповіді мали на меті популяризацію національних здобутків. Мисткиня $є$ членом Міжнародної асоціації бібліотек, архівів, документальних центрів (IAML) (3 1997 р.), Міжнародного товариства «Електронне зображення та візуальні мистецтва» (EVA) (3 2002 р.).

В. Шульгіна є авторкою та співорганізаторкою науковотворчих форумів 3 міжнародною участю в Україні. Серед найбільш значущих: «Старовинна клавірна музика: інструментарій та виконавство» (учасники: швейцарська рада 3 культури «Рro Helvetia», Вища музична школа м. Цюріха та НАКККіМ); «Трансформація освіти і культури: традиції та сучасність (Міністерство культури України, Варшавський музичний університет ім. Ф. Шопена, університет ім. М. Склодовської (Польща, Люблін), Одеська національна музична академія ім. А. Нежданової, НАКККіМ); «Діалог культур: Україна - Греція (Міністерство культури України, НАКККіМ, Український центр культурних досліджень, Інститут культурології НАМУ, Громадська Рада при Міністерстві закордонних справ України, Афінський національний університет ім. Каподистрії, Греція, Університет міста Патри, Греція, університет ім. Аристотеля міста Салоніки, Греція, університет міста Ніш, Республіка Сербія) та ін. [5, с. 328].

Звичайно, проведення таких заходів - складна й відповідальна місія, що потребує організаторських умінь, бажання об'єднати товариство навколо суспільно значущих 
мистецьких цілей. Учениця В. Шульгіної Т. Лестер у своїй статті вказувала на унікальні якості мисткині: «Валерія Дмитрівна - дивовижна людина, вона створює навколо себе особливу атмосферу. Як багато видатних особистостей, володіє магією, приваблює до себе... Дивно спостерігати за тим, наскільки швидко аудиторія (для якої читала лекції В. Д.), що складалася 3 малознайомих один одному людей, перетворювалася на групу однодумців, захоплених обговорюваними питаннями [5, с. 16]».

Паралельно 3 власною дослідницькою діяльністю В. Шульгіна велику увагу приділяе вихованню наукових кадрів. Під іiі керівництвом було захищено понад 20 кандидатських та 10 докторських дисертацій (О. Афоніна, Н. Гуральник, Г. Карась, О. Ізваріна, Ю. Сугробова та ін.). Можемо 3 впевненістю стверджувати, що вже існує інноваційний напрям гуманітаристики, лідеркою якого є Валерія Дмитрівна. Ректор НАКККіМ професор В. Чернець називає вчену берегинею української музикології. Він зазначає, що все національне мистецтвознавство повинно бути вдячне ій за прекрасну школу, провідною ідеєю якої є діалог культур [5, с. 3-4].

Доктор культурології, професор О. Овчарук зазначає: «Знайомлячись із велетенською за своїми масштабами, різновекторною за спрямуванням науковою, педагогічною, громадською, просвітницькою, організаційною працею дослідниці, маючи щасливу долю бути скромним учнем великого Учителя, усвідомлюєш, що здійснити все це можливо тільки людині, наділеній величним талантом Духовності, Доброти, Любові...[4, с. 286]».

Нині В. Шульгіна продовжує успішно здійснювати творчу практику. Ї̈ професійні інтереси - надзвичайно різносторонні: вивчає актуальні питання культурологічної регіоніки, розробляє концептуальні засади теорії мистецтва, аналізує проблеми методики музичної освіти та ін. Вчена працює 3 аспірантами та докторантами. Отож, впевнена - 
наукова думка й надалі поповнюватиметься інтелектуальними здобутками Валерії Дмитрівни.

Висновки. У результаті проведеного аналізу ми прийшли до висновку, що наукова біографія В. Шульгіної $\epsilon$ свідченням яскравої філософії буття креативної неординарної постаті, що зуміла реалізувати багатогранний особистісний потенціал. Працюючи в непростий історичний час, Валерія Дмитрівна змогла бути вільною у своїх життєвих та дослідницьких поглядах, чітко вибудувати поступальну еволюційну стратегію власної творчості.

Практика В. Шульгіної - вагома сторінки в розвитку національної гуманітаристики. Вона здійснюється в декількох магістральних спрямуваннях: започаткування нових мистецтвознавчих, культурологічних та педагогічних напрямків через проведення фундаментальних розвідок; налагодження міжнародної взаємодії 3 провідними освітніми центрами Європи, інтеграція України у світовий соціокультурний простір; підготовка та атестація наукових кадрів (консультування докторантів, керівництво аспірантами; головування та участь у засіданнях спеціалізованих вчених рад, експертної комісії ДАК МOH України; опонування, рецензування авторефератів, науково-методичних видань тощо); провадження організаційної роботи (проведення конференцій, форумів та інших заходів); долучення до підготовки фахових видань та ін.).

Багаторічна плідна діяльність В. Шульгіної відобразила провідні тенденції, актуальні проблеми теорії й практики музичної освіти, питання музичної україніки, культурологічної регіоніки, парадигмальні виміри мистецтва. Інноваційні ідеї вченої отримали подальший розвиток у здобутках іiі численних учнів-послідовників, які, грунтуючись на засадах своєї наставниці, випрацьовують власні методологічні підходи та концепції, що сприяють об'єктивному дослідженню невивчених аспектів національної та європейської культури. 
Дана публікація не вичерпує всі виміри заявленої квестії. Перспективними нам видаються студіювання виконавської, педагогічної роботи В. Шульгіної, аналіз специфіки започаткованих нею мистецтвознавчих напрямів, осягнення особливостей її наукової школи.

\section{Література}

1. Бобришева I. Валерія Шульгіна і висока нота ії життя. URL: http://nbuv.gov.ua/UJRN/bv_1999_2_11.

2. Валерія Шульгіна. Бібліографічний покажчик: до 50-річчя науково-педагогічної діяльності. Укл. О. Вакульчук, Ю. Вінникова. Київ: ДАКККіМ, 2008. 72 с.

3. Ляшко С. Поняття «наукова біографія» у теорії і практиці історико-біографічних

досліджень.

URL: http://nbuv.gov.ua/UJRN/ubi_2013_10_5.

4. Овчарук О. Валерія Шульгіна: грані науково-педагогічного та духовного таланту. Мистецтвознавчі записки. 2009. Вип. 16. C. $280-286$.

5. Синергетична парадигма простору культури: монографія до 50-річчя науково-педагогічної діяльності Валерії Шульгіної. Київ: НАКККіМ, 2014. 400 с.

6. Шульгіна В. Музична україніка: монографія. Київ: НМАУ, 2009. $230 \mathrm{c}$.

7. Шульгіна В., Яковлев О. Інтерпретація теорії культури, мистецтва і освіти в сучасній українській науці (2005-2012рp.). Київ: НАКККіМ, 2012. 228 с. 


\author{
Леся Михайловна Микуланинец, \\ кандидат искусствоведения, доцент, \\ Мукачевский государственный университет, \\ Мукачево, Украина, \\ e-mail: 1.mikulaninets@gmail.com, \\ ORCID: 0000-0002-6346-6532
}

\title{
ИССЛЕДОВАТЕЛЬСКАЯ ДЕЯТЕЛЬНОСТЬ ВАЛЕРИИ ШУЛЬГИНОЙ В ДИСКУРСЕ НАУЧНОЙ БИОГРАФИИ
}

\begin{abstract}
Аннотация. Целью статьи является раскрытие особенностей исследовательской деятельности Валерии Дмитриевны Шульгиной с позиции научной биографии, освещение значения ученой в развитии национальной искусствоведческой мысли. Методология публикации основывается на применении биографического, аналитического, исторического, системного подходов. В работе обосновывается утверждение, что в эпоху постмодернизма художник интерпретатор социокультурных процессов. Изучение его жизнеописания в дискурсе заявленной квестии способствует привлечению в современную гуманитаристику значительного объема неизвестных документов, архивных материалов, мемуарных источников. Они помогают осознать индивидуально-психологические черты креативной персоны, понять логику еe жизненной стратегии, овладеть разными измерениями профессиональной практики, получить конкретный опыт для решения современных онтологических проблем.

Сейчас в искусствоведении важными являются исследования, в которых изучается наследие выдающихся национальных фигур, олицетворяющих движение Украины в европейское цивилизационное пространство. В этом аспекте знаковой является личность В. Шульгиной - автора большого
\end{abstract}


количества фундаментальных трудов. Она основала новые научные направления, воспитала плеяду талантливых ученых. Значительна ее организационная практика, включающая проведение всеукраинских и международных конференций, форумов, творческих встреч. Серьезен вклад Валерии Дмитриевны в подготовку исследовательских кадров посредством: руководства деятельностью аспирантов и докторантов, оппонирования на защитах диссертаций, рецензирования авторефератов, работы в специализированных ученых советах и т.д. Опираясь на идеи В. Шульгиной, представители гуманитаристики активно развивают инновационные методы, познают неизвестные страницы украинской и мировой культуры. Научная биография ученой является свидетельством яркой философии бытия креативной неординарной женщины, сумевшей реализовать собственный многогранный потенциал.

Ключевые слова: жизнеописание, биографический подход, научная биография, гуманитаристика, ученый, исследовательская деятельность, Валерия Шульгина

\author{
Lesya M. Mykulanynets, \\ $\mathrm{PhD}$ in Arts, Associate Professor, \\ Mukachevo State Universitry, \\ Mukachevo, Ukraine, \\ e-mail: 1.mikulaninets@gmail.com, \\ ORCID: 0000-0002-6346-6532
}

\title{
RESEARCH ACTIVITY OF VALERIA SHULGINA IN THE DISCOURSE OF SCIENTIFIC BIOGRAPHY
}

\begin{abstract}
The purpose of the article is to reveal the features of the research activity of Valeriia Shulgina from the scientific biography standpoint, to highlight the importance of the scientist in
\end{abstract}


the development of national art thought. The publication methodology is based on the application of biographical, analytical, historical, systemic approaches. This work substantiates the statement that in the postmodern era the artist is an interpreter of socio-cultural processes. The study of the biography in the discourse of the stated quest contributes the involvement in the modern humanities a significant amount of unknown documents, archival materials, memoirs. They help to understand the individual psychological features of a creative person, the logic of his life strategy, to master the various dimensions of professional practice, to gain concrete experience for solving the modern ontological problems.

Nowadays in art studies the articles on the legacy of prominent national figures who embody Ukraine's progress in the European civilization space are of great important. In this aspect the personality of $\mathrm{V}$. Shulgina, the author of a large number of fundamental works, is significant. She started new scientific directions, brought up a big amount of talented scientists. Her organizational practice is very important; it includes holding Ukrainian and international conferences, forums, and creative meetings. There is a significant contribution of Valeriia Dmytrivna to the preparation of research staff through managing the activities of graduate and doctoral students, opposing dissertations, reviewing abstracts, working in specialized scientific councils, etc. Based on the ideas of V. Shulgina, representatives of the humanities are actively developing innovative methods, learn the unknown pages of Ukrainian and world culture. The artist's scientific biography is a testimony of a creative and extraordinary woman's bright philosophy of existence who managed to realize her own multifaceted potential.

Key words: biography, biographical approach, scientific biography, humanities, scientist, research, Valeria Shulgina 


\section{References}

1. Bobrysheva, I. Valeriia Shulhina i vysoka nota yii zhyttia [Valeriia Shulgina and the high note of her life]. Available at: http://nbuv.gov.ua/UJRN/bv_1999_2_11 [in Ukrainian].

2. Valeriia Shulhina (2008). Bibliohrafichnyi pokazhchyk: do 50-richchia naukovo-pedahohichnoi diialnosti [Bibliographic indicator: to the 50th anniversary of scientific and pedagogical activity]. Ukl.

O. Vakulchuk, Yu. Vinnykova. Kyiv: DAKKKiM [in Ukrainian].

3. Liashko, S. Poniattia "naukova biohrafiia" u teorii i praktytsi istoryko-biohrafichnykh doslidzhen [The concept of "scientific biography" in the theory and practice of historical and biographical research]. Available at: http://nbuv.gov.ua/UJRN/ubi_2013_10_5 [in Ukrainian].

4. Ovcharuk, O. (2009). Valeriia Shulhina: hrani naukovopedahohichnoho ta dukhovnoho talantu [Valeriia Shulgina: the facets of scientific, pedagogical and spiritual talent]. Mystetstvoznavchi zapysky. 16, 280-286 [in Ukrainian].

5. Synerhetychna paradyhma prostoru kultury: monohrafiia do 50-richchia naukovo-pedahohichnoi diialnosti Valerii Shulhinoi (2014). [Synergetic paradigm of cultural space: a monograph to the 50th anniversary of scientific and pedagogical activity of Valeriia Shulgina]. Kyiv: NAKKKiM [in Ukrainian].

6. Shulhina V. (2009). Muzychna ukrainika: monohrafiia [Musical Ukrainian studies: monograph]. Kyiv: NMAU [in Ukrainian].

7. Shulgina, V., Yakovlev, O. (2012). Interpretatsiia teorii kultury, mystetstva i osvity v suchasnii ukrainskii nautsi (2005-2012 rr.) [Interpretation of the theory of culture, art and education in modern Ukrainian science (2005-2012 years)]. Kyiv: NAKKKiM [in Ukrainian]. 